\title{
COMMENT
}

\section{Spawning synchrony in scleractinian corals: Comment on Mangubhai \& Harrison (2008)}

\author{
A. H. Baird ${ }^{1, *}$, J. R. Guest ${ }^{2}$ \\ ${ }^{1}$ ARC Centre of Excellence for Coral Reef Studies, James Cook University, Townsville, Queensland 4811, Australia \\ ${ }^{2}$ School of Biology, Newcastle University, Newcastle upon Tyne NE1 7RU, UK
}

\begin{abstract}
Mangubhai \& Harrison (2008; Mar Ecol Prog Ser 360:85-96) documented spawning patterns in an equatorial assemblage of Acropora spp. in Kenya over a 2 yr period. They concluded that reproductive seasons are more protracted at low latitudes and that 'mass spawning' does not occur in equatorial regions, due to a breakdown in spawning synchrony among species. However, this interpretation hinges on the authors' distinction of 'mass spawning' from 'multi-specific spawning' for which they provide no ecological rationale. Moreover, they did not cite recent studies that document spawning in synchrony by numerous species in equatorial assemblages. In addition, the authors overlooked work demonstrating that spawning is not as synchronous as typically portrayed on the Great Barrier Reef or in Western Australia. In the context of that literature, reproductive patterns of Acropora spp. in Kenya are more similar to sub-tropical reefs in southern Australia rather than to other equatorial reefs. We conclude that the study of reproductive synchrony in corals is being impeded by the lack of a consistent definition that would make it possible to quantify and compare patterns of synchrony at both population and assemblage scales.
\end{abstract}

KEY WORDS: Coral reefs · Reproduction · Spawning

\section{INTRODUCTION}

Mangubhai \& Harrison (2008) used a combination of sequential samples and broad-scale sampling to infer spawning events in 401 colonies in an equatorial assemblage of Acropora spp. in Kenya $\left(4^{\circ} \mathrm{S}\right)$. They concluded that 'the overall pattern of coral reproduction in Kenya is one of asynchrony; Acropora species release gametes over a 7 mo period' (p. 85). Based on these findings, and with reference to the literature, they concluded that 'reproductive seasons may be more protracted towards lower latitudes' and 'mass spawning does not occur in equatorial regions' (p. 91). However, there are 2 problems with these conclusions.

(1) Mangubhai \& Harrison (2008) provide no quantitative definition of 'mass spawning' without which it is difficult to compare patterns in different regions. Furthermore, their conclusion that mass spawning does not occur in equatorial assemblages hinges on the distinction they make between 'mass spawning' and 'multispecific spawning', for which they provide no ecological rationale.

(2) Mangubhai \& Harrison (2008) do not cite studies which indicate that spawning is not as synchronous as typically portrayed on the Great Barrier Reef (GBR) and Western Australia (WA), nor recent studies documenting multispecific synchronous spawning in equatorial assemblages.

\section{MULTISPECIFIC SYNCHRONOUS SPAWNING}

Mangubhai \& Harrison (2008) concluded from their data and reference to Oliver et al. (1988) that mass spawning does not occur in equatorial regions, due to a breakdown in spawning synchrony among species. 
However, Mangubhai \& Harrison (2008) accepted that some level of multispecific spawning synchrony occurs in Kenya:

While the exact night of spawning was recorded in 2 Acropora species, the narrowing of spawning times to lunar months and lunar quarters, and the overlap between reproducing species during these periods suggests that some degree of multispecific spawning is a characteristic of Kenyan reefs.

(Mangubhai \& Harrison 2008, p. 91)

In fact, the spawning period in 12 of 20 Acropora species overlapped during February, the peak month of reproductive output. In addition, Mangubhai \& Harrison (2008) suggested that species from other genera also breed when the Acropora species are breeding. Consequently, their conclusion that mass spawning does not occur in Kenya depends on the authors' distinction of 'mass spawning' from 'multi-specific spawning'. However, no ecological rationale is provided for this distinction, nor is any guide given to how many species, or what proportion of the assemblage constitutes a mass spawning. Mass spawning has previously been defined as the synchronous release of gametes by many species of corals, in one evening between dusk and midnight' (Willis et al. 1985, p. 344), and while a more precise definition is clearly required (see below), by this definition mass spawning has been documented in many other equatorial coral assemblages, including the Java Sea (Edinger et al. in Tomascik et al. 1997), Palau (Penland et al. 2004) and Singapore (Guest et al. 2002). Mangubhai \& Harrison (2008) also concluded that their data challenge the hypothesis of Guest et al. (2005b) that mass spawning is likely to occur in all speciose coral assemblages. In fact, these data from Kenya support this hypothesis, as do data from other sites throughout the Indo-Pacific (Baird et al. 2001, Carroll et al. 2006, Harrison 2008).

\section{LENGTH OF THE REPRODUCTIVE SEASON}

The patterns of reproduction in Kenya were contrasted with the patterns on the GBR and in WA, where mass spawning events were said to be 'unusual in relation to their magnitude and geographic scale' (Mangubhai \& Harrison 2008, p. 85). However, spawning in Acropora assemblages is not as synchronous as typically portrayed for the GBR and WA (Harrison \& Wallace 1990). On the GBR, a number of Acropora species spawn outside of the mass spawning period as defined by Willis et al. (1985). For example, in a 2 yr study of 9 Acropora spp. on Big Broadhurst Reef in the central GBR, A. granulosa spawned in March, 4 mo after the mass spawning period, and some colonies of $A$. sarmentosa were mature in February, August and November (Wallace 1985). Furthermore, in a 3 yr study of spawn- ing times in 12 morphospecies of the Acropora humilis group, a second substantial spawning event occurred 3 mo after the November mass spawning period, with 11 of the 12 taxa participating in both events (Wolstenholme 2004). Colonies of A. samoensis spawned in December, January and February; the majority of colonies of $A$. digitifera spawned in February, and mature colonies of A. gemmifera were present over a 4 mo period (Wolstenholme 2004). High synchrony within populations over a broad spatial scale is the exception on the GBR, rather than the rule. In 3 regions spanning the length of the GBR, most Acropora populations sampled in the week before the mass spawning period had a proportion of colonies in each of 3 reproductive conditions (mature, immature and empty), indicating that spawning in these populations extended over at least 2 mo (Baird et al. 2002). Similarly, the proportion of mature colonies of 3 species of Acropora varied dramatically among 6 regions on the GBR and among years, indicating major regional and annual differences in within-population reproductive synchrony (Hughes et al. 2000). Non-Acropora species known to broadcast spawn outside the accepted mass spawning period on the GBR include: 3 species of Montipora, some colonies of which spawn in both October and March in the central GBR (Stobart et al. 1993); Porites cylindrica and P. lutea, which spawn in January in the Capricorn Bunker Group on the southern GBR (Kojis \& Quinn 1982); and Turbinaria mesenterina, some colonies of which release gametes over a 4 mo period starting in February in the central GBR (Willis 1987). In addition, the first study to claim broad synchrony in spawning among coral assemblages on the GBR actually indicates that spawning was split between November and December on at least 5 of the 12 reefs evaluated, and the number of empty colonies on many reefs suggests that these colonies were breeding at other times of the year (Oliver et al. 1988; their Table 1, p. 805). Similarly, on the west coast of Australia at least 11 species of Acropora spawn in spring (Rosser \& Gilmour 2008), i.e. 6 mo after the accepted mass spawning period (Simpson 1985).

How unusual is a 7 mo reproductive season in the Kenyan Acropora assemblage? Only 2 GBR studies have sampled Acropora assemblages throughout an entire season: on Lizard Island the spawning season lasted at least 5 mo from October to February (Wolstenholme 2004), and on Little Broadhurst Reef spawning was inferred in at least 4 mo between August and March (Wallace 1985). In light of these 2 studies, the length of the reproductive season in Acropora spp. in Kenya is not so extraordinary. Indeed, describing the reproductive season in Kenya as 7 mo long does not capture the fact that peak reproductive output is concentrated in a much shorter period; $80 \%$ of Acropora 
reproductive output occurred between January and March, with $5 \%$ or fewer colonies spawning in October, November, December or April (Mangubhai \& Harrison 2008). The most unusual aspect of the spawning patterns in Kenya is the proportion of species spawning over an extended period: 8 of the 20 species spawn over 3 mo or more, including species such as $A$. nasuta, A. tenuis and A. valida, which typically have high within-population synchrony in other regions (Babcock et al. 1986, Hayashibara et al. 1993). In this respect, spawning patterns in Kenya are more similar to those at sub-tropical sites in southern Australia (Solitary Islands, $30^{\circ} \mathrm{S}$; Wilson \& Harrison 2003), than other equatorial reefs such as Singapore (Guest et al. 2005a). In the Solitary Islands, 9 of the 14 species of Acropora inferred to spawn between December and April released gametes during 3 to 5 mo (Wilson \& Harrison 2003).

\section{A QUANTITATIVE APPROACH TO COMPARING SPAWNING SYNCHRONY AMONG REGIONS}

Reproductive synchrony can occur at several levels, e.g. individual (intra-colony synchrony), species (population synchrony) and coral assemblage (multispecific synchronous spawning or mass spawning). Synchrony may be defined according to the question of interest. For example, if the potential for hybridization among species is the focus, then synchrony must be defined on a time frame that allows cross fertilisation (Levitan et al. 2004, Wolstenholme 2004), and any spawning of more than 1 closely related species is a mass spawning in this context. If we are interested in proximate cues that co-ordinate the day of the month on which a coral species spawns, then a definition of synchrony on the scale of days will suffice. If we are interested in proximate cues for the seasonality of spawning, the month of spawning will suffice.

A quantitative approach is essential for comparing synchrony between sites and among species. For studying seasonality, an index should be devised that incorporates the proportion of the population that spawns in any one month and the number of months of the year in which spawning occurs; averaging the values for all species sampled would provide an index of the seasonality of spawning in the assemblage. Mangubhai \& Harrison (2008) provide important new information on the patterns of coral spawning in equatorial Kenya, but these patterns do not demonstrate that spawning synchrony breaks down near the equator. Testing of this hypothesis requires more than 1 equatorial site and an equivalent examination of replicate assemblages at higher latitudes. Furthermore, a quantitative definition of synchrony is a prerequisite for testing such a hypothesis. We conclude that progress towards understanding the proximate and ultimate cues that synchronise coral spawning requires more rigour in defining spawning synchrony.

Acknowledgements. This research was partly supported by a Japan Society for Promotion of Science short term Scientific Fellowship and Australian Research Council funding to A.H.B.

\section{LITERATURE CITED}

Babcock RC, Bull GD, Harrison PL, Heyward AJ, Oliver JK, Wallace CC, Willis BL (1986) Synchronous spawnings of 105 scleractinian coral species on the Great Barrier Reef. Mar Biol 90:379-394

Baird AH, Sadler C, Pitt M (2001) Synchronous spawning of Acropora in the Solomon Islands. Coral Reefs 19:286

Baird AH, Marshall PA, Wolstenholme J (2002) Latitudinal variation in the reproduction of Acropora in the Coral Sea. Proc 9th Int Coral Reef Symp 1:385-389

> Carroll A, Harrison PL, Adjeroud M (2006) Sexual reproduction of Acropora reef corals at Moorea, French Polynesia. Coral Reefs 25:93-97

Guest JR, Chou LM, Baird AH, Goh BPL (2002) Multispecific, synchronous coral spawning in Singapore. Coral Reefs 21: 422-423

Guest JR, Baird AH, Goh BPL, Chou LM (2005a) Reproductive seasonality in an equatorial assemblage of scleractinian corals. Coral Reefs 24:112-116

Guest JR, Baird AH, Goh BPL, Chou LM (2005b) Seasonal reproduction in equatorial reef corals. Invertebr Reprod Dev 48:207-218

Harrison PL (2008) Coral spawn slicks at Lord Howe Island, Tasman Sea, Australia; the world's most southerly coral reef. Coral Reefs 27:35

Harrison PL, Wallace CC (1990) Reproduction, dispersal and recruitment of scleractinian corals. In: Dubinsky Z (ed) Coral reefs, Vol 25. Elsevier, Amsterdam, p 133-207

> Hayashibara T, Shimoike K, Kimura T, Hosaka S and others (1993) Patterns of coral spawning at Akajima Island, Okinawa, Japan. Mar Ecol Prog Ser 101:253-262

Hughes TP, Baird AH, Dinsdale EA, Moltschaniwskyj NA, Pratchett MS, Tanner JE, Willis BL (2000) Supply-side ecology works both ways: the link between benthic adults, fecundity, and larval recruits. Ecology 81:2241-2249

Kojis BL, Quinn NJ (1982) Reproductive strategies in four species of Porites (Scleractinia). Proc 4th Int Coral Reef Symp 2:145-151

Levitan DR, Fukami H, Jara J, Kline D and others (2004) Mechanisms of reproductive isolation among sympatric broadcast-spawning corals of the Montastraea annularis species complex. Evolution 58:308-323

> Mangubhai S, Harrison PL (2008) Asynchronous coral spawning patterns on equatorial reefs in Kenya. Mar Ecol Prog Ser 360:85-96

Oliver JK, Babcock RC, Harrison PL, Willis BL (1988) Geographic extent of mass spawning: clues to ultimate causal factors. Proc 6th Int Coral Reef Symp 2:803-810

Penland L, Kloulechad J, Idip D, van Woesik R (2004) Coral spawning in the western Pacific Ocean is related to solar insolation: evidence of multiple spawning events in Palau. Coral Reefs 23:133-140

Rosser NL, Gilmour JP (2008) New insights into patterns of coral spawning on Western Australian reefs. Coral Reefs $27: 345-349$ 
Simpson CJ (1985) Mass spawning of scleractinian corals in the Dampier Archipelago and the implications for management of coral reefs in Western Australia. Rep No. 244, Bull Dept Conservation Environment Western Australia, Perth

Stobart B, Babcock RC, Willis BL (1993) Biannual spawning of three species of scleractinian coral from the Great Barrier Reef. Proc 7th Int Coral Reef Symp 1:494-499

Tomascik T, Mah AJ, Nontij A, Moosa MK (1997) The ecology of the Indonesian Seas, Vol 1. Periplus, Hong Kong

Wallace CC (1985) Reproduction, recruitment and fragmentation in nine sympatric species of the coral genus Acropora. Mar Biol 88:217-233

Willis BL (1987) Morphological variation in the reef corals Turbinaria mesenterina and Pavona cactus: synthesis of

Editorial responsibility: Matthias Seaman,

Oldendorf/Luhe, Germany transplant, histocompatibility electrophoresis, growth and reproduction studies. PhD thesis, James Cook University, Townsville

Willis BL, Babcock RC, Harrison PL, Oliver JK (1985) Patterns in the mass spawning of corals on the Great Barrier Reef from 1981 to 1984. Proc 5th Int Coral Reef Symp 4:343-348

- Wilson JR, Harrison PL (2003) Spawning patterns of scleractinian corals at the Solitary Islands - a high latitude coral community in eastern Australia. Mar Ecol Prog Ser 260: 115-123

Wolstenholme JK (2004) Temporal reproductive isolation and gametic compatibility are evolutionary mechanisms in the Acropora humilis species group (Cnidaria; Scleractinia). Mar Biol 144:567-582

Submitted: July 4, 2008; Accepted: November 17, 2008

Proofs received from author(s): December 12, 2008 